\title{
Cytotoxicity of Reactive Oxygen Species and Related Agents Toward Undifferentiated and Differentiated Rat Phenochromocytoma PC12 Cells
}

\author{
Naoko SASAKI, ${ }^{a}$ Naomichi BABA, ${ }^{b}$ and Mitsuyoshi MATSUO $*, a$ \\ Department of Biology, Faculty of Science and High Technology Research Center, Konan University, ${ }^{a}$ 8-9-1 Okamoto, \\ Higashinadaku, Kobe 658-8501, Japan and Department of Bioresources Chemistry, Faculty of Agriculture, Okayama \\ University, ${ }^{b}$ 1-1-1 Tsushimanaka, Okayama 700-8530, Japan. $\quad$ Received January 9, 2001; accepted February 1, 2001
}

\begin{abstract}
The cytotoxicity of reactive oxygen species and related agents toward cultured rat adrenal medullary phenochromocytoma PC12 cells was examined. These species and agents include hydrogen peroxide, linoleic acid hydroperoxide (LOOH), tert-butyl hydroperoxide, paraquat, 2,2'-azobis(2-amidinopropane) dihydrochloride (AAPH), 2,2'-azobis(2,4-dimethylvaleronitrile) (AMVN), and a hypoxanthine-xanthine oxidase system. The respective $50 \%$ lethal concentrations $\left(\mathrm{LC}_{50}\right)$ for undifferentiated and differentiated PC12 cells were found to be 275 and $165 \mu \mathrm{M}$ of hydrogen peroxide, 58.3 and $35.3 \mu \mathrm{M}$ of LOOH, 536 and $212 \mu \mathrm{M}$ of tert-butyl hydroperoxide, 42.5 and $26.5 \mathrm{~mm}$ of paraquat, 79.5 and $74.5 \mathrm{~mm}$ of AAPH, 412 and $300 \mu \mathrm{M}$ of AMVN, and 37.2 and $16.6 \mathrm{mU} \cdot \mathrm{ml}^{-1}$ xanthine oxidase activity of the hypoxanthine-xanthine oxidase system. These results show that the differentiated cells were more susceptible to these oxidative agents than the undifferentiated cells. The glutathione peroxidase activity level of the undifferentiated cells was $2-3$ times higher than the differentiated cells, the catalase activity level also tended to be higher, the superoxide dismutase activity level was higher on a per-protein-quantity basis but lower on a per-cell-number basis, and the total and reduced glutathione concentration levels were considerably higher. The enhanced susceptibility of the differentiated cells may result from decreases in the activity of glutathione peroxidase and the concentration of its substrate, reduced glutathione (GSH). Further, the preincubation of PC12 cells with $\alpha$-tocopherol or L-buthionine-(R,S)-sulfoximine (BSO) lowered or enhanced their cytotoxicities, respectively.
\end{abstract}

Key words PC12 cells; cytotoxicity; reactive oxygen species; linoleic acid hydroperoxide; glutathione peroxidase; glutathione

It has been suggested that reactive oxygen species-induced oxidative stress may play important roles in the etiology of neurodegenerative diseases, such as Alzheimer's disease and Parkinson's disease, which are intimately associated with neuronal death. ${ }^{1)}$ It is unknown, however, how oxidative stress damages neuronal cells. Understanding of the cytotoxicity of reactive oxygen species and related free radicals (hereafter referred to as radicals) toward neuronal cells is necessary for the mechanistic clarification of neuronal damage due to oxidative stress.

The PC12 cell line was initially derived from a rat adrenal medullary phenochromocytoma. ${ }^{2}$ When grown in a serumcontaining medium, PC12 cells divide and resemble precursors of adrenal chromaffin cells and sympathetic neurons. Upon addition of the nerve growth factor (NGF), these "naive" cells gradually attain the phenotypic properties of sympathetic neurons. ${ }^{3)}$ Thus, the PC12 cell line is used as a model system of neuronal cells.

In the present study, we examined the cytotoxicity of hydrogen peroxide (a typical, relatively stable reactive oxygen species), LOOH (a lipid peroxide and fat-soluble, radicalgenerating agent), tert-butyl hydroperoxide (a commercially available hydroperoxide and amphipathic, radical-generating agent), paraquat (a superoxide radical-generating agent), AAPH (a water-soluble, radical-generating agent), AMVN (a fat-soluble, radical-generating agent), and a hypoxanthinexanthine oxidase system (a superoxide radical and hydrogen peroxide-generating agent) toward undifferentiated and differentiated PC12 cells. These $\mathrm{LC}_{50}$ 's revealed that linoleic acid hydroperoxide was highly toxic, hydrogen peroxide, tert-butyl hydroperoxide, and AMVN were significantly toxic, and paraquat and AAPH were slightly toxic. The hypoxanthine-xanthine oxidase system also was toxic. It was further observed that the differentiated cells were more sus- ceptible to these oxidative agents than the undifferentiated cells, and that the glutathione peroxidase activity and reduced glutathione concentration levels of the former were much lower as compared with the latter.

\section{MATERIALS AND METHODS}

Materials Hydrogen peroxide (30\%), AAPH, AMVN, DL- $\alpha$-tocopherol, and trypan blue were purchased from Wako Chemical Industries (Osaka, Japan), and tert-butyl hydroperoxide, paraquat $\left(1,1^{\prime}\right.$-dimethyl-4,4'-bipyridinium dichloride), BSO, and NGF from Sigma-Aldrich Co. (St. Louis, MO, U.S.A.). LOOH [(9Z,11E)-13-hydroperoxy-9,11-octadecadienoic acid] was prepared with soybean lipoxygenase as described previously. ${ }^{4}$ The RPMI1640 medium was obtained from Nissui Pharmaceutical Co., Ltd. (Tokyo, Japan), a 0.2\% collagen solution in Hank's buffer at $\mathrm{pH} 7.4$ from Koken Corporation (Tokyo, Japan), fetal bovine serum (FBS) from Moregate Laboratories (Melbourne, Australia) and PAAL Laboratories (Newport Beach, CA, U.S.A.), and horse serum from Moregate Laboratories. The horse serum was inactivated at $56^{\circ} \mathrm{C}$ for $30 \mathrm{~min}$. PC12 cells came from the Japanese Health Sciences Foundation (Osaka, Japan). Falcon 10$\mathrm{cm}$ plastic plates and 24-well plastic plates were purchased from Becton Dickinson Labware (Lincoln Park, NJ, U.S.A.). The other materials were obtained from ordinary commercial sources.

Cell Culture Cell cultivation was conducted at $37^{\circ} \mathrm{C}$ in a humidified atmosphere of 5\% carbon dioxide and $95 \%$ air. Cell counting was done with a Coulter counter (Model Z-1, Coulter Corporation, Hialeah, FL, U.S.A.).

Undifferentiated PC12 cells were inoculated at a density of $2.1 \times 10^{4} \mathrm{cells} \cdot \mathrm{cm}^{-2}$ in $10-\mathrm{cm}$ plastic plates, each of which contained $8 \mathrm{ml}$ of the RPMI1640 medium supplemented with 
$5 \%$ FBS and $10 \%$ horse serum, and cultivated. The cells were subcultivated every $4 \mathrm{~d}$ at a $3: 1$ split ratio by pipetting. The medium was changed $2 \mathrm{~d}$ after inoculation.

For differentiation, the undifferentiated cells were inoculated at a density of $5.0 \times 10^{3}$ cells $\cdot \mathrm{cm}^{-2}$ in $0.2 \%$ collagencoated 24-well plastic plates, each well of which contained $1 \mathrm{ml}$ of the $0.5 \%$ heat-inactivated horse serum and 200 $\mathrm{ng} \cdot \mathrm{ml}^{-1} \mathrm{NGF}$-supplemented RPMI1640 medium, and cultivated for $5 \mathrm{~d}$. The medium was changed $3 \mathrm{~d}$ after inoculation.

Quantification of Cytotoxicity Undifferentiated PC12 cells were inoculated at a density of $5.0 \times 10^{4}$ cells $\cdot \mathrm{cm}^{-2}$ in 24-well plastic plates, each well of which contained $1 \mathrm{ml}$ of the FBS and horse serum-supplemented medium, and cultivated overnight; the differentiated cells were cultivated for $5 \mathrm{~d}$ under the same conditions for differentiation as described above. After removal of the media, cells in each well were washed with $1 \mathrm{ml}$ of calcium and magnesium-free phosphatebuffered saline at $\mathrm{pH} 7.4$, and incubated for $1.5 \mathrm{~h}$ in $1 \mathrm{ml}$ of Earle's solution containing a reactive oxygen species or related agent at an appropriate concentration. For inclusion of AMVN, the FBS and horse serum-supplemented medium was used instead of Earle's solution because of its low solubility. A hypoxanthine-xanthine oxidase system was constituted of $500 \mu \mathrm{M}$ hypoxanthine and an appropriate activity of xanthine oxidase. The $\%$ survival of cells was determined by the trypan blue exclusion test. ${ }^{5)}$ The $\mathrm{LC}_{50}$ of each oxidative agent is estimated graphically on the survival curves of cells in Fig. 1.

Administration of $\alpha$-Tocopherol or L-Buthionine- $(R, S)$ sulfoximine to Cells Before exposure to each oxidative agent, cells were preincubated with $\alpha$-tocopherol or BSO. $\alpha$ Tocopherol was solubilized in ethanol at a concentration of $16.6 \mathrm{~mm}$. Cells were preincubated for $24 \mathrm{~h}$ at $37^{\circ} \mathrm{C}$ either in 24-well plastic plates, each well of which contained $3 \mu \mathrm{l}$ of the $\alpha$-tocopherol solution and $1 \mathrm{ml}$ of the FBS and horse serum-supplemented medium, or in collagen-coated 24-well plastic plates, each well of which contained $3 \mu \mathrm{l}$ of the $\alpha$-tocopherol solution and $1 \mathrm{ml}$ of the horse serum and NGF-supplemented medium, i.e., $50 \mu \mathrm{m} \alpha$-tocopherol.

BSO was dissolved in the RPMI1640 medium at a concentration of $16.6 \mathrm{~mm}$. Cells were preincubated for $24 \mathrm{~h}$ at $37^{\circ} \mathrm{C}$ either in 24-well plastic plates, each of which contained $3 \mu \mathrm{l}$ of the BSO-supplemented medium and $1 \mathrm{ml}$ of the FBS and horse serum-supplemented medium, or in collagen-coated 24-well plastic plates, each of which contained $3 \mu \mathrm{l}$ of the BSO-supplemented medium and $1 \mathrm{ml}$ of the horse serum and NGF-supplemented medium, i.e., $50 \mu \mathrm{m}$ BSO.

Antioxidant Index of $\alpha$-Tocopherol- or L-Buthionine$(\boldsymbol{R}, \boldsymbol{S})$-sulfoximine-Preincubated Cells For estimation of the antioxidant capacity of $\alpha$-tocopherol- or BSO-preincubated cells, the antioxidant index (AI) of these cells is defined as follows:

$$
\mathrm{AI}=\frac{\mathrm{LC}_{50} \text { of an agent for } \alpha \text {-tocopherol- or BSO-preincubated cells }}{\mathrm{LC}_{50} \text { of the same agent for control cells }}
$$

Thus, $\mathrm{AI}>1$ and $\mathrm{AI}<1$ mean the increasing and decreasing antioxidant capacities of cells, respectively.

Biochemical Analysis Superoxide dismutase activity was assayed by the method of Oyanagi, ${ }^{6}$ ) catalase activity by that of Del Rio et al., ${ }^{7)}$ glutathione peroxidase activity by that of Flohé and Günzler, ${ }^{8)}$ and reduced and oxidized glutathione concentrations by that of Griffith. ${ }^{9)}$ Protein content was measured by the method of Bradford. ${ }^{10}$ )

The catalase-catalyzed formation of molecular oxygen from hydrogen peroxide was assayed with an oxygen monitor (model 5300, YSI Inc., Yellow Springs, OH, U.S.A.).

Statistical Analysis Data in Table 2 and Fig. 1 are expressed as mean values with the corresponding standard deviation. Mean values were assessed for significance by Student's $t$-test; $p$-values $<0.05$ were considered significant. Statistical analysis was performed using a Macintosh G3 computer (Apple Computer, Inc., Cupertino, CA, U.S.A.) with the Stat-View SE software program (Abacus Concepts, Inc., Berkeley, CA, U.S.A.).

\section{RESULTS}

Figures $1 \mathrm{~A}-\mathrm{G}$ show the survival curves of undifferentiated and differentiated PC12 cells exposed to reactive oxygen species or related agents at different concentrations. Table 1 shows the $\mathrm{LC}_{50}$ of these oxidative agents for PC12 cells. For the undifferentiated cells, $\mathrm{LOOH}$ was highly toxic at an $\mathrm{LC}_{50}$ of $58.8 \mu \mathrm{M}$, and hydrogen peroxide, tert-butyl hydroperoxide, and AMVN were significantly toxic at those of 275, 536, and $412 \mu \mathrm{M}$, respectively. Since the $\mathrm{LC}_{50}$ of AMVN could not be measured because of insolubility at a concentration of more than $300 \mu \mathrm{M}$, it was estimated by extrapolation in Fig. 1E. Paraquat and AAPH were slightly toxic. A hypoxanthinexanthine oxidase system also was toxic, although this toxicity is not compared with the toxicity of the other agents directly.

For the differentiated cells, $\mathrm{LOOH}$ was highly toxic at an $\mathrm{LC}_{50}$ of $35.3 \mu \mathrm{M}$, and hydrogen peroxide, tert-butyl hydroperoxide, and AMVN were significantly toxic at those of 165 , 212 , and $300 \mu \mathrm{M}$, respectively, while paraquat and AAPH were slightly toxic. The hypoxanthine-xanthine oxidase system also was toxic. It is of great interest that the differentiated cells were more susceptible to the oxidative agents, except AAPH, than the undifferentiated cells.

Table 2 shows the activities of superoxide dismutase, catalase, and glutathione peroxidase and the concentrations of total, reduced, and oxidized glutathione in undifferentiated and differentiated PC12 cells. The total superoxide dismutase activity level of the undifferentiated cells was higher on a per-protein-quantity basis than that of the differentiated cells, but much lower on a per-cell-number basis. The catalase activity level of the undifferentiated cells was higher on a percell-number basis than that of the differentiated cells, although the difference between the levels is statistically insignificant on a per-protein-quantity basis. The glutathione peroxidase activity level of the undifferentiated cells was 23 times higher than that of the differentiated cells. The GSH concentration level of the undifferentiated cells was higher by $40 \%$ on a per-cell-number basis and by $32 \%$ on a per-protein-quantity basis than that of the differentiated cells. The oxidized glutathione (GSSG) concentration levels of these cells were similar. The percentages of reduced and oxidized glutathione were 85.4 and $14.6 \%$, respectively, for the undifferentiated cells, and 80.6 and $19.4 \%$, respectively, for the differentiated cells. Further, the total glutatione concentration level of the undifferentiated cells was higher by $37 \%$ on a per-cell-number basis and by $27 \%$ on a per-protein-quantity 

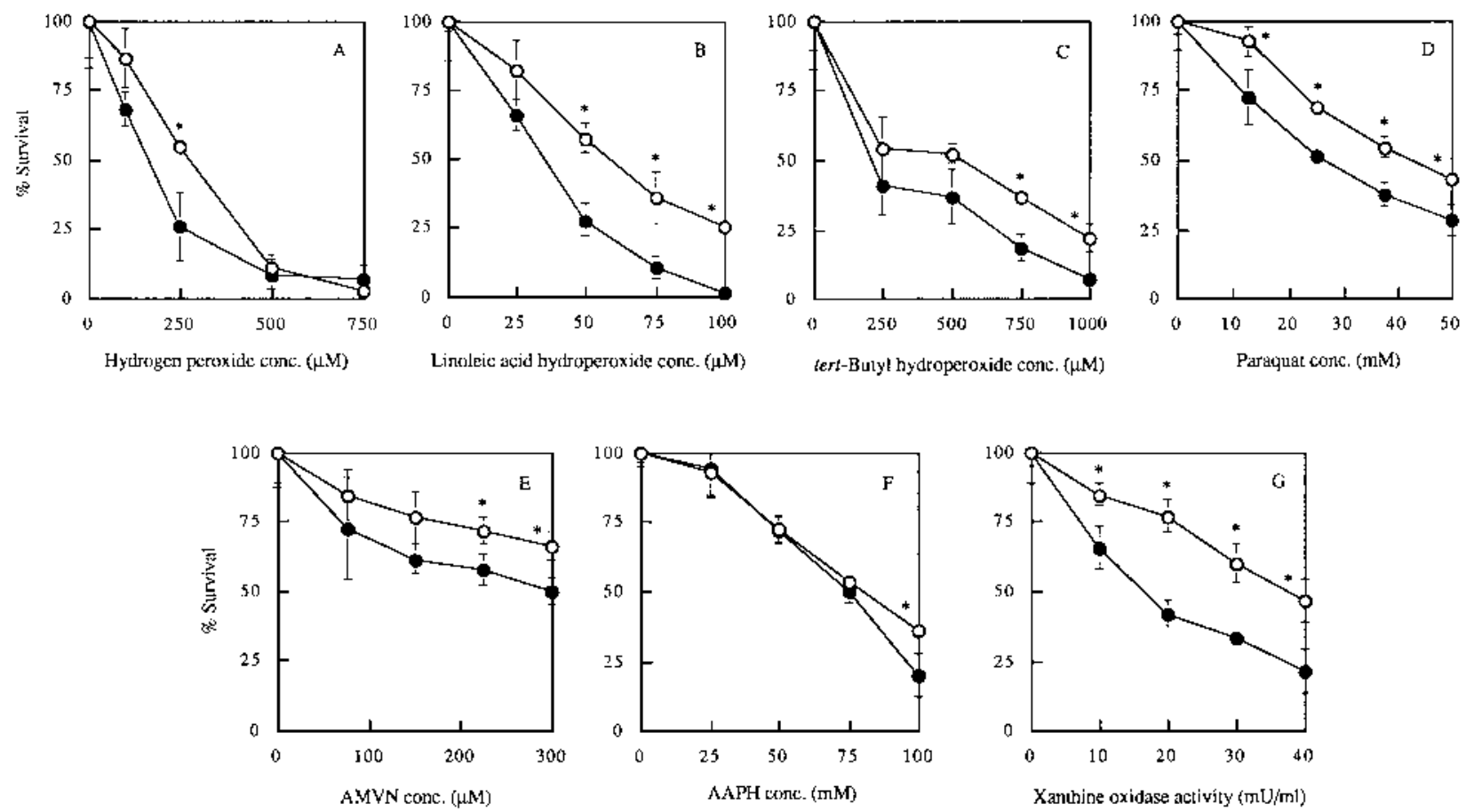

Fig. 1. Survival Curves of Undifferentiated and Differentiated PC12 Cells Exposed to Reactive Oxygen Species or Related Agents at Different Concentrations

Cells were exposed for $1.5 \mathrm{~h}$ at $37^{\circ} \mathrm{C}$ to hydrogen peroxide (A), linoleic acid hydroperoxide (B), tert-butyl hydroperoxide (C), paraquat (D), $2,2^{\prime}$-azobis(2-amidinopropane) dihydrochloride $(\mathrm{F})$, or a hypoxanthine-xanthine oxidase system $(\mathrm{G})$ in Earle's solution, or to 2,2' -azobis(2,4-dimethylvaleronitrile) (E) in the 5\% fetal bovine serum and $10 \%$ horse serum-supplemented RPMI1640 medium. Open and closed symbols show the \% survivals of the undifferentiated and differentiated cells, respectively. Each symbol represents the mean value for three cell cultures, and the error bar represents its standard deviation. Each asterisk means that the difference between the value of the undifferentiated cells and the corresponding value of the differentiated cells is statistically significant $(p<0.05)$.

Table 1. 50\% Lethal Concentration of Reactive Oxygen Species and Related Agents toward Undifferentiated and Differentiated PC12 Cells

\begin{tabular}{lcc}
\hline \hline \multirow{2}{*}{ Agent } & \multicolumn{2}{c}{$\left.\mathrm{LC}_{50}{ }^{a}\right)$} \\
\cline { 2 - 3 } & Undifferentiated cells & Differentiated cells \\
\hline Hydrogen peroxide & $275 \mu \mathrm{M}$ & $165 \mu \mathrm{M}$ \\
LOOH $^{b)}$ & $58.3 \mu \mathrm{M}$ & $35.3 \mu \mathrm{M}$ \\
tert $^{-B u t y l ~ h y d r o p e r o x i d e ~}$ & $536 \mu \mathrm{M}$ & $212 \mu \mathrm{M}$ \\
Paraquat $_{\text {AMVN }}$ & $42.5 \mathrm{mM}$ & $26.5 \mathrm{mM}$ \\
AAPH $^{e}$ & $412 \mu \mathrm{M}$ & $300 \mu \mathrm{M}$ \\
Xanthine oxidase $^{f)}$ & $79.5 \mathrm{mM}$ & $74.5 \mathrm{mM}$ \\
& $37.2 \mathrm{mU} \cdot \mathrm{ml}^{-1}$ & $16.6 \mathrm{mU} \cdot \mathrm{ml}^{-1}$ \\
\hline
\end{tabular}

a) $50 \%$ Lethal concentration: cells were incubated for $1.5 \mathrm{~h}$ at $37^{\circ} \mathrm{C}$ with each agent in Earle's solution, except for AMVN in the 5\% fetal bovine serum and $10 \%$ horse serum-supplemented RPMI1640 medium. b) Linoleic acid hydroperoxide [(9Z,11E)13-hydroperoxy-9,11-octadecadienoic acid]. c) 2,2'-Azobis(2,4-dimethylvaleronitrile). d) This value was obtained by extrapolation in Fig. $1 \mathrm{E}$ because of insolubility at a concentration of more than $300 \mu \mathrm{M}$. e) 2,2'-Azobis(2-amidinopropane) dihydrochloride. $f$ ) The hypoxanthine-xanthine oxidase system with $500 \mu \mathrm{m}$ hypoxanthine.

basis than that of the differentiated cells.

The $\mathrm{LC}_{50}$ of the oxidative agents for the undifferentiated (Table 3 ) and differentiated cells (Table 4) which were preincubated with $\alpha$-tocopherol or BSO was examined. $\alpha$-Tocopherol lowered the cytotoxicity of the oxidative agents, except that of the hypoxanthine-xanthine oxidase system, toward both the undifferentiated and differentiated cells (AI $1.2-4.8$ ) and, interestingly, also lowered the cytotoxicity of $\mathrm{LOOH}$ (3.4 and 4.8, respectively) to a greater extent. In addition, $\alpha$-tocopherol tended to be more protective toward the differentiated cells than toward the undifferentiated cells. On the other hand, BSO enhanced the cytotoxicity of the oxida- tive agents (AI 0.19-0.56) except those of hydrogen peroxide, $\mathrm{LOOH}$, and tert-butyl hydroperoxide toward the undifferentiated cells $(0.81-0.98)$.

\section{DISCUSSION}

On the basis of the $\mathrm{LC}_{50}$ 's obtained here, the cytotoxicity increases in the following order: $\mathrm{LOOH}>$ hydrogen peroxide $>$ AMVN $>$ tert-butyl hydroperoxide $>$ paraquat $>$ AAPH. In comparison between these cytotoxicities, however, it should be noted that the reactive species-generating mechanisms of the oxidative agents differ.

$\mathrm{LOOH}$ is lipophilic and both hydrogen peroxide and tertbutyl hydroperoxide are amphipathic; all three can be incorporated into cells. Furthermore, $\mathrm{LOOH}$, hydrogen peroxide, and tert-butyl hydroperoxide are converted to oxygen-centered radicals, such as the hydroxyl and alkoxyl radicals, by the aid of iron(II) and/or copper(I) ions.

Both AAPH and AMVN are azo compounds. AAPH is water-soluble and is thought to exist outside cells. AMVN is fat-soluble and is thought to be incorporated into plasma membranes. On thermolysis at ambient temperature, AAPH and AMVN decompose into carbon-centered radicals with release of molecular nitrogen, i.e., the 1-amidino-1-methylethyl radical hydrochloride and 1-cyano-1,3-dimethylbutyl radical, respectively, which are converted to the 1-amidino-1methylethylperoxyl radical hydrochloride and 1-cyano-1,3dimethylbutylperoxyl radical, respectively, at almost diffusion-controlled rates in the presence of molecular oxygen. The 1-amidino-1-methylethyl radical hydrochloride and 1amidino-1-methylethylperoxyl radical hydrochloride derived 
Table 2. Relative Activities of Superoxide Dismutase, Catalase, and Glutathione Peroxidase and Relative Concentrations of Total, Reduced, and Oxidized Glutathione in Undifferentiated and Differentiated PC12 Cells

\begin{tabular}{|c|c|c|c|c|c|c|}
\hline \multirow{3}{*}{ Enzyme } & \multicolumn{6}{|c|}{ Relative activity $(\%)^{a}$} \\
\hline & \multicolumn{2}{|c|}{ Total SOD } & \multicolumn{2}{|c|}{ Catalase } & \multicolumn{2}{|c|}{ Glutathione perxidase } \\
\hline & per cells & per protein & per cells & per protein & per cells & per protein \\
\hline Undifferentiated cells & $100 \pm 1^{b)}$ & $100 \pm 1^{b)}$ & $100 \pm 9$ & $100 \pm 8^{b)}$ & $100 \pm 1^{b)}$ & $100 \pm 2^{b)}$ \\
\hline \multirow[t]{2}{*}{ Differentiated cells } & $153 \pm 5$ & $83.1 \pm 1.9$ & $95.5 \pm 5.0$ & $77.8 \pm 3.3$ & $41.1 \pm .9$ & $30.2 \pm 1.7$ \\
\hline & \multicolumn{6}{|c|}{ Relative concentration $(\%)^{a)}$} \\
\hline \multirow[t]{2}{*}{ Glutathione } & \multicolumn{2}{|c|}{ Total } & \multicolumn{2}{|c|}{ Reduced $^{c)}$} & \multicolumn{2}{|c|}{ Oxidized $^{c)}$} \\
\hline & per cells & per protein & per cells & per protein & per cells & per protein \\
\hline Undifferentiated cells & $100 \pm 6^{b)}$ & $100 \pm 8^{b)}$ & $100 \pm 8^{b)}$ & $100 \pm 9^{b)}$ & $100 \pm 1^{b)}$ & $100 \pm 10$ \\
\hline Differentiated cells & $63.5 \pm 3.7$ & $72.2 \pm 4.3$ & $62.6 \pm 5.1$ & $71.4 \pm 6.5$ & $68.3 \pm 14.5$ & $77.7 \pm 14.2$ \\
\hline
\end{tabular}

a) Each value represents the mean value and the corresponding standard deviation for three cell cultures. $\quad b$ ) The difference between the value of the undifferentiated cells and the corresponding value of the differentiated cells is statistically significant $(p<0.05) . \quad c)$ The percentages of reduced and oxidized glutathione are 85.4 and $14.6 \%$, respectively, for the undifferentiated cells, and 80.6 and $19.4 \%$, respectively, for the differentiated cells.

Table 3. $50 \%$ Lethal Concentration of Reactive Oxygen Species and Related Agents toward Undifferentiated PC12 Cells Preincubated with $\alpha$-Tocopherol or L-Buthionine- $(R, S)$-sulfoximine

\begin{tabular}{|c|c|c|c|}
\hline \multirow{2}{*}{ Agent } & \multicolumn{3}{|c|}{$\mathrm{LC}_{50}^{a}$} \\
\hline & None & $\alpha$-Tocopherol ${ }^{b)}$ & $\mathrm{BSO}^{c)}$ \\
\hline Hydrogen peroxide & $275 \mu \mathrm{M}$ & $342 \mu \mathrm{M}(1.2)^{d)}$ & $135 \mu \mathrm{M}(0.49)$ \\
\hline $\mathrm{LOOH}^{e)}$ & $58.8 \mu \mathrm{M}$ & $199 \mu \mathrm{M}(3.4)$ & $32.9 \mu \mathrm{M}(0.56)$ \\
\hline tert-Butyl hydroperoxide & $536 \mu \mathrm{M}$ & $750 \mu \mathrm{M}(1.4)$ & $185 \mu \mathrm{M}(0.35)$ \\
\hline Paraquat & $42.5 \mathrm{~mm}$ & $65.9 \mathrm{~mm}(1.5)$ & $8.10 \mathrm{~mm}(0.19)$ \\
\hline Xanthine oxidase ${ }^{f}$ ) & $37.6 \mathrm{mU} \cdot \mathrm{ml}^{-1}$ & $\begin{array}{l}40.0 \mathrm{mU} \cdot \mathrm{ml}^{-1} \\
\quad(1.1)\end{array}$ & $\begin{array}{l}8.80 \mathrm{mU} \cdot \mathrm{ml}^{-1} \\
\quad(0.23)\end{array}$ \\
\hline
\end{tabular}

a) See footnote $a$ to Table 1. b) Cells were preincubated with $50 \mu \mathrm{M} \alpha$-tocopherol for $24 \mathrm{~h} . \quad c$ ) Cells were preincubated with $50 \mu \mathrm{M}$ L-buthionine- $(R, S)$-sulfoximine for $24 \mathrm{~h} . d$ ) Antioxidant indices are shown in parentheses (see text). $e, f$ ) See footnotes $b$ and $f$ to Table 1 .

Table 4. 50\% Lethal Concentration of Reactive Oxygen Species and Related Agents toward Differentiated PC12 Cells Preincubated with $\alpha$-Tocopherol or L-Buthionine- $(R, S)$-sulfoximine

\begin{tabular}{|c|c|c|c|}
\hline \multirow{2}{*}{ Agent } & \multicolumn{3}{|c|}{$\left.\mathrm{LC}_{50}{ }^{a}\right)$} \\
\hline & None & $\alpha$-Tocopherol $^{b)}$ & $\mathrm{BSO}^{c)}$ \\
\hline Hydrogen peroxide & $165 \mu \mathrm{M}$ & $321 \mu \mathrm{M}(1.9)^{d)}$ & $150 \mu \mathrm{M}(0.91)$ \\
\hline $\mathrm{LOOH}^{e)}$ & $35.6 \mu \mathrm{M}$ & $170 \mu \mathrm{M}(4.8)$ & $28.8 \mu \mathrm{M}(0.81)$ \\
\hline tert-Butyl hydroperoxide & $220 \mu \mathrm{M}$ & $692 \mu \mathrm{M}(3.1)$ & $216 \mu \mathrm{M}(0.98)$ \\
\hline Paraquat & $26.8 \mathrm{~mm}$ & $59.5 \mathrm{~mm}(2.1)$ & $14.5 \mathrm{~mm}(0.54)$ \\
\hline Xanthine oxidase ${ }^{f)}$ & $16.8 \mathrm{mU} \cdot \mathrm{ml}^{-1}$ & $\begin{array}{l}14.3 \mathrm{mU} \cdot \mathrm{ml}^{-1} \\
\quad(0.85)\end{array}$ & $\begin{array}{l}7.96 \mathrm{mU} \cdot \mathrm{ml}^{-1} \\
\quad(0.47)\end{array}$ \\
\hline
\end{tabular}

$a-f$ ) See footnotes to Table 3 .

from AAPH are water-soluble. The 1-cyano-1,3-dimethylbutyl radical and 1-cyano-1,3-dimethylbutylperoxyl radical from AMVN are fat-soluble. It has been reported that the rate of radical flux $\left(\mathrm{M} \cdot \mathrm{s}^{-1}\right)$ from AAPH in neutral water at $37^{\circ} \mathrm{C}$ is $1.36 \times 10^{-6}$ [AAPH]; ${ }^{11)}$ a compound between square brackets represents its molar concentration. Thus, $584 \mathrm{nmol}$ of the 1-amidino-1-methylethyl radical hydrochloride is calculated to arise during a $1.5 \mathrm{~h}$-incubation at $37^{\circ} \mathrm{C}$ in $1 \mathrm{ml}$ of the medium with $79.5 \mathrm{~mm}$ AAPH $\left(\mathrm{LC}_{50}\right.$ for the undifferentiated cells). If all the radicals produced are accumulated in the medium, the final concentration will be $584 \mu \mathrm{M}$. On the other hand, the rate of radical flux $\left(\mathrm{M} \cdot \mathrm{s}^{-1}\right)$ from AMVN in acetonitrile at $37^{\circ} \mathrm{C}$ is estimated to be $3.88 \times 10^{-6}$ [AMVN], since the rate of radical flux from it at $0.5 \mathrm{~mm}$ has been reported to be $1.94 \times 10^{-9} \mathrm{M} \cdot \mathrm{s}^{-1}$ under the same reaction conditions. ${ }^{12)}$ Thus, $8.63 \mathrm{nmol}$ of the 1-cyano-1,3-dimethylbutyl radical is calculated to arise during a $1.5 \mathrm{~h}$-incubation at $37^{\circ} \mathrm{C}$ in $1 \mathrm{ml}$ of the medium with $412 \mu \mathrm{M}$ AMVN ( $\mathrm{LC}_{50}$ for the undifferentiated cells). If all the radicals produced are accumulated in the medium, the final concentration will be $8.63 \mu \mathrm{M}$. Consequently, AMVN is considered to be extremely toxic and AAPH to be significantly toxic. The difference between their cytotoxicities may result from the difference in their lipophilicities and the lipophilicities of the radicals derived from them.

In the presence of molecular oxygen, xanthine oxidase catalyzes initially to convert hypoxanthine to xanthine and, in turn, to convert the xanthine to uric acid. ${ }^{13)}$ In each oxidation step, both the superoxide radical and hydrogen peroxide are produced. It has been reported that $20 \%$ of molecular oxygen consumed is converted to the superoxide radical ${ }^{14)}$ in the following oxidation of xanthine with xanthine oxidase: ${ }^{15)}$

$$
\begin{aligned}
& \text { xanthine }+2 \mathrm{O}_{2}+\mathrm{H}_{2} \mathrm{O} \rightarrow \text { uric acid }+2 \mathrm{O}_{2}{ }^{-}+2 \mathrm{H}^{+} \\
& \text {xanthine }+\mathrm{O}_{2}+\mathrm{H}_{2} \mathrm{O} \rightarrow \text { uric acid }+\mathrm{H}_{2} \mathrm{O}_{2}
\end{aligned}
$$

The superoxide radical produced may be converted to hydrogen peroxide and molecular oxygen by superoxide dismutase-catalyzed dismutation and/or spontaneous dismutation. One unit of xanthine oxidase used converts about $0.5 \mu \mathrm{mol}$ of hypoxanthine to uric acid in $1 \mathrm{~min}$ at $\mathrm{pH} 7.5$ at $25^{\circ} \mathrm{C} .{ }^{16}$ ) Assuming that $2 \mathrm{~mol}$ of hydrogen peroxide is yielded in the xanthine oxidase-catalyzed oxidation of $1 \mathrm{~mol}$ of hypoxanthine into urate, $8.0 \mu \mathrm{mol}$ of hydrogen peroxide is calculated to arise during a $1.5 \mathrm{~h}$-incubation at $37^{\circ} \mathrm{C}$ in $1 \mathrm{ml}$ of the hypoxanthine-xanthine oxidase system containing $500 \mu \mathrm{M}$ hypoxanthine and $37.2 \mathrm{mU} \cdot \mathrm{ml}^{-1}$ xanthine oxidase $\left(\mathrm{LC}_{50}\right.$ for the 
undifferentiated cells). If all hydrogen peroxide produced is accumulated in the medium, the final concentration will be $8.0 \mathrm{~mm}$. This is about 29 times as compared with $275 \mu \mathrm{M}$ to be the $\mathrm{LC}_{50}$ of hydrogen peroxide. The antioxidant defense of cells appears to efficiently scavenge hydrogen peroxide continuously generated from the hypoxanthine-xanthine oxidase system.

From one electron reduction of paraquat, the paraquat cation radical is formed, which is expected to reduce molecular oxygen to the superoxide radical. ${ }^{17)}$ It has been found that paraquat is actively imported by cells and metabolized with NADPH cytochrome P-450 reductase to the cation radical. ${ }^{18)}$ The generation rate of the superoxide radical from paraquat may depend on its reduction rate.

Table 1 and Fig. 1 show that the differentiated cells were more susceptible to the oxidative agents than the undifferentiated cells. Table 2 shows that the glutathione peroxidase activity and GSH concentration levels of the differentiated cells were much lower than those of the undifferentiated cells, that the catalase activity level of the former was lower on a perprotein-quantity basis, and further that the superoxide dismutase activity level of the former was lower on a per-proteinquantity basis but higher on a per-cell-number basis. Glutathione peroxidase, as well as catalase, scavenges hydrogen peroxide and GSH acts as its substrate. The enhanced susceptibility of the differentiated cells may result from the decreases in glutathione peroxidase activity and GSH concentration. The activities of antioxidant enzymes have been found to be lower in the central nervous system than in other tissues. ${ }^{19,20)}$ The increased susceptibility of the differentiated cells might reflect the antioxidant capacity of neuronal cells.

Perez-Polo and his colleagues have reported, however, that as compared wtih undifferentiated PC12 cells, the differentiated cells were more resistant to hydrogen peroxide and their catalase and glutathione peroxidase activities increased. ${ }^{21,22)}$ These results are inconsistent with ours. This discrepancy might result from a difference in the experimental conditions used and/or from a difference in the subclones of PC12 cells, because PC12 cells are prone to produce characteristically different subclones. ${ }^{3)}$

$\alpha$-Tocopherol acts as a radical scavenger and chain-breaking antioxidant, because it donates its phenolic hydrogen atom to a radical and gives rise to the $\alpha$-tocopheroxyl radical which is converted to nonradical species. ${ }^{23)}$ By preincubation with $\alpha$-tocopherol, the antioxidant capacity of cells thus increases. Incidentally, it has been observed that when endothelial cells are preincubated with $50 \mu \mathrm{M} \alpha$-tocopherol for $24 \mathrm{~h}$ at $37^{\circ} \mathrm{C}$, their cellular concentration increases about 80 fold. ${ }^{24)}$ Tables 3 and 4 show that $\alpha$-tocopherol is protective against the cytotoxicity of the oxidative agents. $\alpha$-Tocopherol is more protective against the cytotoxicity of $\mathrm{LOOH}$ and less protective against the cytotoxicities of hydrogen peroxide and the hypoxantine-xanthine oxidase system. Both $\alpha$ tocopherol and $\mathrm{LOOH}$ are highly lipophilic and hence may be considerably retained in plasma membranes. Consequently, $\alpha$-tocopherol may efficiently scavenge the reactive species derived from $\mathrm{LOOH}$.

On the other hand, BSO inhibits $\gamma$-glutamylcysteine syn- thetase. Because $\gamma$-glutamylcysteine is a precursor of GSH, its cellular concentration is markedly lowered in BSO-preincubated cells. ${ }^{25}$ In fact, after preincubation with $50 \mu \mathrm{M}$ BSO, the intracellular concentration of GSH was reduced by 88.1 and $90.6 \%$ in undifferentiated and differentiated PC12 cells, respectively (data not shown). GSH is the substrate of glutathione peroxidase and an abundant biological reductant, which acts as the first line of antioxidant defense. Thus, by preincubation with BSO the antioxidant capacity of cells is decreased. Tables 3 and 4 show that BSO enhanced the cytotoxicity of the oxidative agents. However, BSO had no effects on the cytotoxicities of hydrogen peroxide, $\mathrm{LOOH}$, or tertbutyl hydroperoxide toward the differentiated cells (Table 4). As shown in Table 2, the glutathione peroxidase activity and GSH concentration levels of the differentiated cells decreased greatly. It is plausible, therefore, that further decreases in these levels no longer enhance their cytotoxicities.

Acknowledgments We thank Prof. E. Niki of Utsunomiya University for his helpful advice about the rate of radical flux from AMVN.

\section{REFERENCES}

1) Halliwell B., Gutteridge J. M. C., "Free Radicals in Biology and Medicine," 3rd ed., Oxford University Press, Oxford, 1999, pp. 736-761.

2) Greene L. A., Tischler A. S., Proc. Natl. Acad. Sci. U.S.A., 73, 2424 2428 (1976).

3) Fujita K., Lazarovici P., Guroff G., Environ. Health Perspectives, 80, 127-142 (1989).

4) Kaneko T., Matsuo M., Chem. Pharm. Bull., 32, 332-335 (1984).

5) McAteer J. A., Davis J., "Basic Cell Culture, a Practical Approach," ed. by Davis J. M., IRL Press, Oxford, 1994, pp. 128-130.

6) Oyanagi Y., Anal. Biochem., 142, 290-296 (1984).

7) Del Rio L. A., Ortega M. G., López A. L., López Gorgé J., Anal. Biochem., 80, 409-415 (1979).

8) Flohé L., Günzler W. A., Methods Enzymol., 105, 114-121 (1984).

9) Griffith O. W., Anal. Biochem., 106, 207-212 (1980).

10) Bradford M. M., Anal. Biochem., 72, 248-254 (1976).

11) Nik E., Methods Enzymol., 186, 100-108 (1990).

12) Shi H., Noguchi N., Niki E., Free Radic. Biol. Med., 27, 334-356 (1999).

13) Escribano J., Garcia-Canovas F., Garcia-Carmona F., Biochem. J., 254, 829-833 (1988).

14) Fridovich I., J. Biol. Chem., 254, 4053-4057 (1970).

15) Terada L. S., Leff J. A., Repine J. E., Methods Enzymol., 186, 651656 (1990).

16) Sigma General Catalog, Japanese edition, 1999, p. 1070.

17) Farrington J. A., Ebert M., Land E. J., Fletcher K., Biochim. Biophys. Acta, 314, 372-381 (1973).

18) Horton J. K., Brigelius R., Mason R. P., Bend J. R., Mol. Pharmacol., 29, $484-488$ (1986).

19) Matsuo M., Gomi F., Dooley M. M., Mech. Ageing Dev., 64, 273 295 (1992).

20) Savolainen H., Res. Commun. Chem. Pathol. Pharmacol., 21, 173176 (1978).

21) Jackson G. R., Apffel L., Werrbach-Perez K., Perez-Polo J. R., J. Neurosci. Res., 25, 360-368 (1990).

22) Sampath D., Jackson G. R., Werrbach-Perez K., Perez-Polo J. R., J. Neurochem., 62, 2476-2479 (1994).

23) Matsuo M., Kaneko T., "Methods in Aging Research," ed. by Yu B. P., CRC Press, Boca Raton, FL, 1998, pp. 571-606.

24) Kaneko T., Nakano S., Matsuo M., Lipids, 26, 345-348 (1991).

25) Honda S., Matsuo M., Biochem. Internat., 18, 439-446 (1989). 